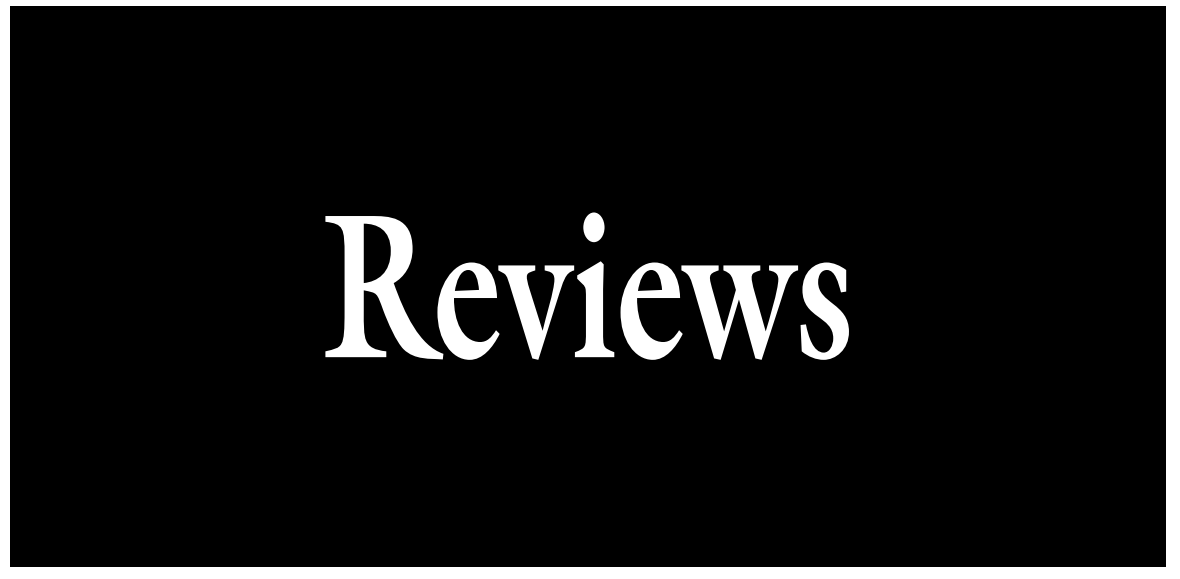

\title{
Fifty-five Years of Yield Improvement for Cucumber, Melon, and Watermelon in the United States
}

\author{
Gabriele Gusmini and Todd C. Wehner ${ }^{1}$
}

\begin{abstract}
AdDITIONAL Index wORDs. Cucumis sativus, Cucumis melo, Citrullus lanatus, statistical reporting, production, vegetable breeding

Summary. Yield data for the major cucurbit crops in the United States have been collected and summarized. Yield trends are presented for cucumber (Cucumis sativus; processing and fresh-market), melon (Cucumis melo; muskmelon and honeydew), and watermelon (Citrullus lanatus) for the period 1951-2005. Data have been obtained from the U.S. Department of Agriculture, as originally reported by six of its units: Agricultural Marketing Service, Agricultural Research Service, Bureau of Agricultural Economics, Economic Statistics Service, National Agricultural Statistics Service, and Statistical Reporting Service. For all crops yields have been increasing over time, except for processing cucumber, for which yields seem to have reached a plateau by the end of the 1990s.
\end{abstract}

$\mathrm{T}$ he cucurbit crops (Cucurbitaceae) that are grown most commonly in the United States are cucumber, melon, and watermelon. In 2005 , U.S. production was 570,720 tons of processing cucumbers, 10,232 thousand cwt of fresh-market cucumbers, 22,120 thousand cwt of muskmelons, 4505 thousand cwt of honeydew melons, and 37,896 thousand cwt of watermelons (U.S. Department of Agriculture, National Agricultural Statistics Service, 2006).

High yield can be achieved by improving cultural practices and by developing genetically superior cultivars. Production researchers and plant breeders have been interested in increasing yield because they would

Department of Horticultural Science, North Carolina State University, Box 7609, Raleigh, NC 276957609

${ }^{1}$ Corresponding author. E-mail: todd_wehner@ncsu.edu. like to maximize crop production efficiency and because of higher demand for food by the expanding population of the world. High-yielding cultivars, precision-farming systems, increased use of chemicals for fertilization and weed and disease control, and proper training of the local farmers allowed a significant change in agriculture. As a result, crop yields have increased and many crops are now successfully grown worldwide.

Statistical records for yield and production of cucumbers, melons, and watermelons in the United States were available from the U.S.
Department of Agriculture for 19512005 (U.S. Department of Agriculture, Agricultural Marketing Service, 1957a, b; U.S. Department of Agriculture, Agricultural Research Service, 1998, 1999a, 2000, 2001, 2002, 2003, 2004; U.S. Department of Agriculture, Bureau of Agricultural Economics, 1953a, 1953b; U.S. Department of Agriculture, Economic Statistics Service, 1981, 1985; U.S. Department of Agriculture, National Agricultural Statistics Service, 1989, 1999b, 2006; U.S. Department of Agriculture, Statistical Reporting Service, 1961, 1962, 1967a, 1967b, 1972, 1977a, 1977b). Yield data were provided separately for processing (pickling) and fresh-market (slicing) cucumbers, and for muskmelon and honeydew melons (Fig. 1). Yield data were partly missing in the 1980s for cucumbers because of interruption of the census. These additional data would have been very useful to determine better the trend for these crops in that decade. It is of great importance that census of major horticultural crops not be interrupted in the future, to perform accurate historical analyses. Yield data have been reported by government sources cited earlier using different units of measurement in different years (bushels, hundredweights, crates per acre) for the same crop. One of our objectives was to compare yield changes and magnitude among types and within crop (i.e., honeydew melon vs. muskmelon melon and processing vs. fresh-market cucumber). Therefore, we needed to standardize all measurements in a comparable scale. We chose to use metric tons per hectare and, thus, transformed all data into this unit of measurement.

At the beginning of the 1950s, fresh-market cucumbers had twice the yield of processing cucumbers (8.6 vs. $4.3 \mathrm{Mg} \cdot \mathrm{ha}^{-1}$ respectively; Fig. 1A). Nevertheless, available data show that the yield of processing cucumbers reached a plateau in the 1980s, with values fluctuating

\begin{tabular}{llll}
\hline $\begin{array}{l}\text { Units } \\
\begin{array}{l}\text { To convert U.S. to SI, } \\
\text { multiply by }\end{array}\end{array}$ & U.S. unit & SI unit & $\begin{array}{l}\text { To convert SI to U.S., } \\
\text { multiply by }\end{array}$ \\
\hline 45.3592 & $\mathrm{cwt}$ & $\mathrm{kg}$ & 0.0220 \\
0.0454 & $\mathrm{cwt}$ & $\mathrm{Mg}$ & 22.0462 \\
0.9072 & ton(s) & $\mathrm{Mg}$ & 1.1023 \\
2.2417 & ton/acre & $\mathrm{Mg} \cdot \mathrm{ha}^{-1}$ & 0.4461
\end{tabular}


Reviews
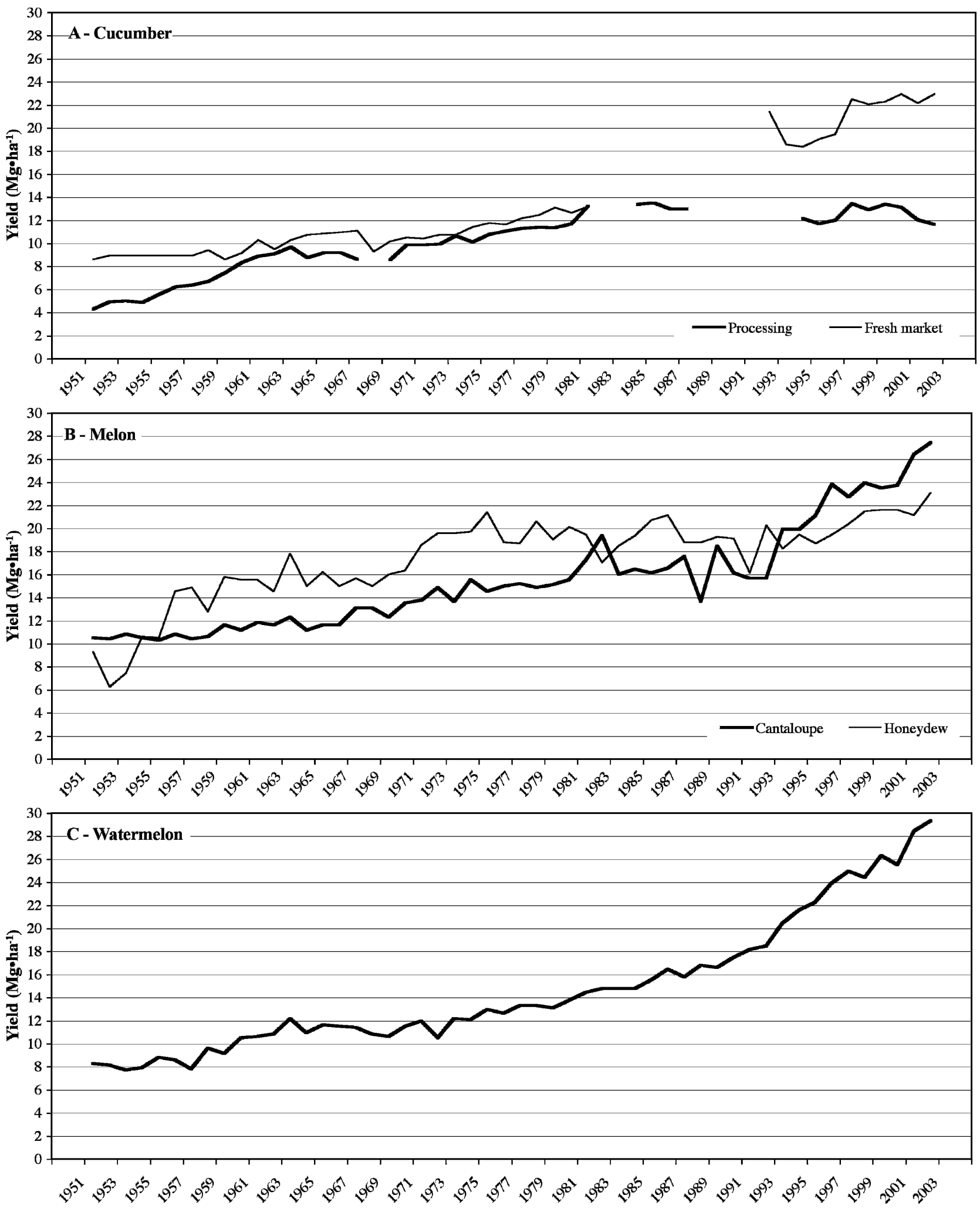

Fig. 1. (A-C) Yield of cucumber (A), melon (B), and watermelon (C) between 1951 and 2005 in the United States. Data were originated by the Statistical Reporting Service and the Economic Research Service of the U.S. Department of Agriculture. Missing data were from years of interruption of the census. $1 \mathrm{Mg} \cdot \mathrm{ha}^{-1}=0.4461 \mathrm{ton} / \mathrm{acre}$.

between 11.6 and $11.2 \mathrm{Mg} \cdot \mathrm{ha}^{-1}$ between 1985 and 2005. Dependence on just a few cultivars of processing cucumbers may account for this plateau. Processing cucumbers are usually purchased by a small number of pickling companies that encourage the use of particular cultivars by the growers to maintain the uniformity of their products. Furthermore, pickling companies have been concentrating their contracts with fewer highly specialized growers who are able to produce a higher yield per unit area, thus making the production system more

10

Horlechnology · January-March 2008 18(1) 
efficient. Fresh-market cucumbers, instead, recorded increasing yields for the same period, gaining more than $10 \mathrm{Mg} \cdot \mathrm{ha}^{-1}$.

Yields of muskmelon and honeydew melons had similar trends for the second half of the 20th century (Fig. 1B). Yield improvement has been slow but constant for these crops, with an approximate threefold increase during the 50-year period. The yield of muskmelons changed from 10.3 to $11.6 \mathrm{Mg} \cdot \mathrm{ha}^{-1}$ in the $1950 \mathrm{~s}$ and $1960 \mathrm{~s}$ to $27.8 \mathrm{Mg} \cdot \mathrm{ha}^{-1}$ in 2005. The yield of honeydew melons increased from less than $10 \mathrm{Mg} \cdot \mathrm{ha}^{-1}$ in the 1950s to a peak of 27.8 $\mathrm{Mg} \cdot \mathrm{ha}^{-1}$ in 2005. Honeydew melon yield was lower than that of muskmelon between 1951 and 1955, whereas it was higher between 1955 and 1993. After 1993, muskmelon yield was higher than honeydew melon yield. The trend for melons indicates a faster increase in yield in the 1990s than earlier, with muskmelon yield increasing more rapidly than honeydew melon yield. The higher yield of muskmelon can be explained by the longer harvest window (usually 10$14 \mathrm{~d}$ vs. One to three consecutive harvests of honeydew melons) and by the larger size of honeydew melons, which may induce a lower number of fruit per plant. It is also interesting to notice that until the end of the 1990s, most honeydew melon cultivars were open pollinated, whereas muskmelon cultivars were already Fl hybrids, indicating a greater breeding effort in this segment.

Watermelon had the greatest yield increase in the last half century among the three species surveyed here (Fig. 1C). In the United States, watermelons yielded between 7.7 and 9.6 Mg.ha ${ }^{-1}$ in the $1950 \mathrm{~s}$, and 31.1 $\mathrm{Mg} \cdot \mathrm{ha}^{-1}$ in 2005. As for cucumbers and melons, the greatest yield increases in watermelon were recorded after the mid 1980s.

Higher inputs for the cultivation of cucurbits may have contributed to the yield increase of these crops, particularly after the 1970s. By the 1980s, many of the common cultural practices had been mechanized, and weed and disease control were facilitated by the use of new chemicals. Finally, irrigation systems had become a common practice in vegetable production. Furthermore, the use of row covers (Wells and Loy,
1985), plastic mulches, fumigants, and drip irrigation under the mulch (Bonanno, 1996; Decoteau et al., 1989) allowed the exclusion of weeds from the cultivation bed and improved the control of soil-borne plant pathogens. The use of drip irrigation allowed efficient delivery of macro- and micronutrients to the plants as needed, thus better exploiting their genetic yield potential.

The late 1980s and 1990s appears to be a period of transition during which cultural practices favoring higher yields became more widespread year after year, until they become the norm, and efforts made by plant breeders to improve input traits (yield, disease resistance, plant type, general agricultural characteristics) finally come to fruition. During this period, mechanized agriculture, specialized fertilization and irrigation techniques, highly efficient disease control programs, and superior cultivars were all available to growers and became basic components of a highly evolved and technically advanced agriculture.

Little heterosis has been observed in cucumber, melon, or watermelon (Cramer and Wehner, 1999; Gusmini and Wehner, 2005; Wehner, 1999). Thus, increases in yield cannot be highly correlated with the change from open-pollinated cultivars to $\mathrm{F}_{1}$ hybrids that has occurred during the last two decades. Nevertheless, examples of heterosis in specific crosses exist (Brar and Sidhu, 1977; Brar and Sukhija, 1977; Nandpuri et al., 1974, 1975; Sidhu and Brar, 1977, 1985; Sidhu et al., 1977a, b), so it is possible that heterosis has contributed to a yield increase for specific cultivars. The overall quality and percentage of marketable yield over total has also increased as a result of breeding efforts (Gusmini and Wehner, 2005). The small advantage in yield of hybrids also indicates that their use was most likely preferred over open-pollinated cultivars for other reasons, such as easy introduction in heterozygous condition of disease resistance genes (dominant alleles) and for protection of proprietary genes by private breeders and seed companies.

Overall, it is difficult to determine whether plant breeding or improved production practices contributed the most to the yield increase observed in cucumbers, melons, and watermelons after the 1950s. Our review has demonstrated positive trends for yield improvement for the three major groups of cucurbits in the United States. On the other hand, yield of processing cucumbers seems to have reached a plateau and, it is difficult to predict if and when this trend will change in the future.

\section{Literature cited}

Bonanno, A.R. 1996. Weed management in plasticulture. HortTechnology 6:186189.

Brar, J.S. and A.S. Sidhu. 1977. Heterosis and combining ability of earliness and quality characters in watermelon (Citrullus lanatus (Thunb. Mansf.). II. J. Res $14: 272-278$.

Brar, J.S. and B.S. Sukhija. 1977. Hybrid vigor in inter-varietal crosses in watermelon (Citrullus lanatus (Thunb) Mansf.). Indian J. Hort 34:277-283.

Cramer, C.S. and T.C. Wehner. 1999. Little heterosis for yield and yield components in hybrids of six cucumber inbreds. Euphytica 110:99-108.

Decoteau, D.R., M.J. Kasperbauer, and P.G. Hunt. 1989. Mulch surface color affects yield of fresh-market tomatoes. J. Amer. Soc. Hort. Sci. 114:216-219.

Gusmini, G. and T.C. Wehner. 2005. Foundations of yield improvement in watermelon. Crop Sci. 45:141-146.

Nandpuri, K.S., J.C. Kumar, and G.S. Dhillon. 1974. Heterosis in watermelon. Punjab Hort. J. 14:75-83.

Nandpuri, K.S., J.C. Kumar, and G.S. Dhillon. 1975. Combining ability estimates in a set of top crosses in watermelon (Citrullus lanatus Sch.). Punjab Hort. J. 15:65-70.

Sidhu, A.S. and J.S. Brar. 1977. Heterosis and combining ability of yield and its components in watermelon (Citrullus lanatus (Thunb.) Mansf.). J. Res. 14:52-58.

Sidhu, A.S. and J.S. Brar. 1985. Genetic divergence and hybrid performance in watermelon. Indian J. Agr. Sci. 55:459461.

Sidhu, A.S., J.S. Brar, and S.P.S. Gill. 1977a. Mode of inheritance and gene action for yield and its components in watermelon (Citrullus lanatus (Thumb) Mansf). J. Res. Punjab Agr. Univ. 14: 419-422.

Sidhu, A.S., J.S. Brar, and S.P.S. Gill. 1977b. Mode of inheritance of earliness and quality characters in watermelon 
(Citrullus lanatus (Thumb) Mansf). J. Res. Punjab Agr. Univ. 14:423-426.

U.S. Department of Agriculture, Bureau of Agricultural Economics. 1953a. Commercial vegetables for fresh market. U.S. Dept. Agr., Washington, DC.

U.S. Department of Agriculture, Bureau of Agricultural Economics. 1953b. Vegetables for commercial processing. U.S. Dept. Agr., Washington, DC.

U.S. Department of Agriculture, Agricultural Marketing Service. 1957a. Vegetables for fresh market. U.S. Dept. Agr., Washington, DC.

U.S. Department of Agriculture, Agricultural Marketing Service. 1957b. Vegetables for processing. U.S. Dept. Agr., Washington, DC.

U.S. Department of Agriculture, Statistical Reporting Service. 1961. Vegetables for processing. U.S. Dept. Agr., Washington, DC.

U.S. Department of Agriculture, Statistical Reporting Service. 1962. Vegetables for fresh market. U.S. Dept. Agr., Washington, DC.

U.S. Department of Agriculture, Statistical Reporting Service. 1967a. Vegetables for fresh market. U.S. Dept. Agr., Washington, DC.

U.S. Department of Agriculture, Statistical Reporting Service. 1967b. Vegetables for processing. U.S. Dept. Agr., Washington, DC.
U.S. Department of Agriculture, Statistical Reporting Service. 1972. Vegetables for fresh market. U.S. Dept. Agr., Washington, DC.

U.S. Department of Agriculture, Statistical Reporting Service. 1977a. Vegetables for fresh market. U.S. Dept. Agr., Washington, DC.

U.S. Department of Agriculture, Statistical Reporting Service. 1977b. Vegetables for processing. U.S. Dept. Agr., Washington, DC.

U.S. Department of Agriculture, Economic Statistics Service. 1981. Vegetables. U.S. Dept. Agr., Washington, DC.

U.S. Department of Agriculture, Economic Statistics Service. 1985. Vegetables. U.S. Dept. Agr., Washington, DC.

U.S. Department of Agriculture, National Agricultural Statistics Service. 1989. Vegetables. U.S. Dept. Agr., Washington, DC.

U.S. Department of Agriculture, Agricultural Research Service. 1998. Statistics of vegetables and melons. U.S. Dept. Agr., Washington, DC.

U.S. Department of Agriculture, Agricultural Research Service. 1999a. Statistics of vegetables and melons. U.S. Dept. Agr., Washington, DC.

U.S. Department of Agriculture, National Agricultural Statistics Service. 1999b. Vegetables. U.S. Dept. Agr., Washington, DC.
U.S. Department of Agriculture, Agricultural Research Service. 2000. Statistics of vegetables and melons. U.S. Dept. Agr., Washington, DC.

U.S. Department of Agriculture, Agricultural Research Service. 2001. Statistics of vegetables and melons. U.S. Dept. Agr., Washington, DC.

U.S. Department of Agriculture, Agricultural Research Service. 2002. Statistics of vegetables and melons. U.S. Dept. Agr., Washington, DC.

U.S. Department of Agriculture, Agricultural Research Service. 2003. Statistics of vegetables and melons. U.S. Dept. Agr., Washington, DC.

U.S. Department of Agriculture, Agricultural Research Service. 2004. Statistics of vegetables and melons. U.S. Dept. Agr., Washington, DC.

U.S. Department of Agriculture, National Agricultural Statistics Service. 2006. Agricultural statistics database: QuickSTAT. 15 July 2006. <www.nass.usda.gov:81/ ipedb/>.

Wehner, T.C. 1999. Heterosis in vegetable crops, p. 387-397. In: J.G. Coors and S. Pandey (eds.). The genetics and exploitation of heterosis in crops. ASA-CSSASSSA, Madison, WI.

Wells, O.S. and J.B. Loy. 1985. Intensive vegetable production with row covers. HortScience 20:822-826. 